\title{
En doktor og et tapet i Surnadal
}

Heinrich P. Bauer (1785-1863) hadde en forhistorie som militærlege i Tyskland og (som fange) i Frankrike i napoleonstiden, før han ble Corpslæge for Romsdalske Corps og bosatte seg i Surnadal på Nordmøre. Her restaurerte han en gårdsbygning, og tapetet han benyttet finnes i gårdens stue den dag i dag. Bauers historie er mer ærerik enn lokalhistorien vil ha det til.

\section{Dag Brekke}

da-bre@online.no

Sunnaas sykehus

Under et oppdrag i Surnadal ble jeg kontaktet av Ingebrigt B. Moen, som nå bor på gården Austistua (gnr. 15, bnr. 1). Han fortalte litt om dr. Bauer og at de hadde bevart tapetet som han hadde satt opp i stuen da han bodde på gården.
På begynnelsen av 1800-tallet var det fire leger i Romsdals Amt, som Møre og Romsdal het den gang. En av dem var Corpslæge ved Romsdalske Corps, Heinrich Philip Bauer, som fra 1833 praktiserte i Surnadal $(1,2)$.

Lokalhistorikeren Hans Hyldbakk (3) skriver om ham:

«Segna sa at han hadde rømt frå krigen i heimlandet. Etter at han kom hit til bygda var han dokter åt soldatane på Skeismoen, men nokon framifrå lækjar skulle han ikkje vera. Det skulle vera mest kaldvatn han brukte som lækjeråd, og difor vart han gjernast kalla for Kallvass-Baur. (...) Det var Bauer som sette dei i stand (gardshusa) med tapet og paneling alle stader. Han var det og som bygde den framifrå potetkjellaren under husa med steinkjelving over.»

For anledningen gjengis hva som er skrevet om dr. Bauer i verket Norges Leger (4) (gjengitt i språkdrakten fra 1873):

«Bauer, Heinrich Philip, 1785-1863, Corpslæge. Han var født i Osterode am Hartz 17. Martz «1785», deltog som Saarlæge i de fransk-tydske Krige paa Napo-

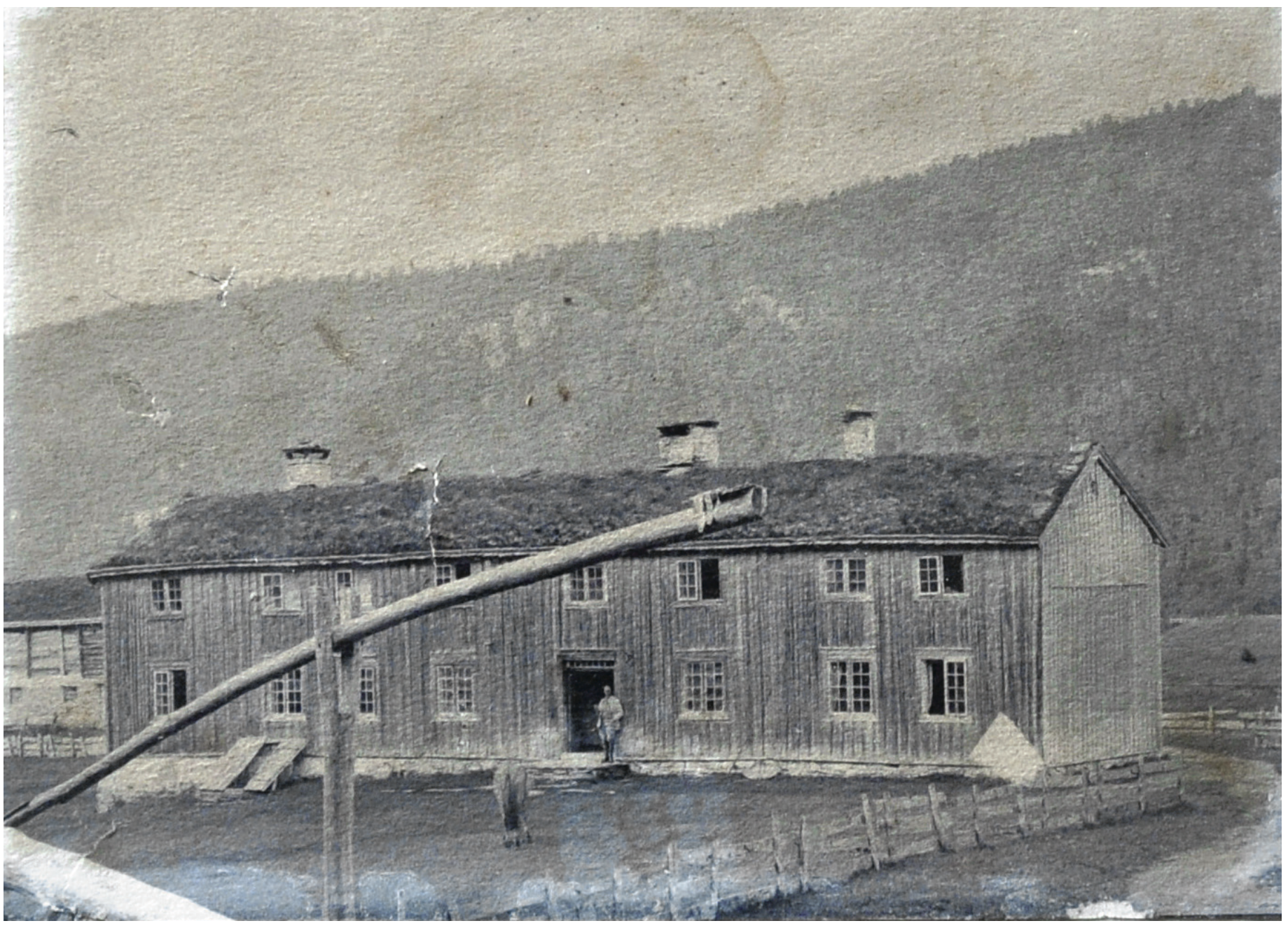

Austistua Moen rundt år 1900. Kontrasten mellom husets ytre og finstua på gården måtte oppleves som betydelig. Stua med tapetet er i 1. etasje til høyre. Foto: ukjent 
leons Tid og blev i Hamburg fangen af de Franske under Bernadotte. I det halve Aar, Fangenskabet varede, gjorde han Tjeneste som Læge ved de franske Tropper. I Anledning af Krigen med Sverige i 1808 blev han af Sundhedscollegiet i Kiel engageret som Læge ved den norske Armee og ankom til Christiansand i Juli s.A. I Krigsaarene 1808-14 gjorde han Tjeneste paa flere Steder i det søndenfjeldske Norge, først som Compagnichirurg og fra 4. Aug. 1811 som Bataillonschirurg ved 2det Trondhjemske Infanteri-Regiment, i 1818 stod han som Bataillonschirurg ved Romsdalske nationale Musketercorps, og i Aaret 1819 blev han ansatt som Corpslæge ved samme Afdeling. Fra denne stilling erholdt han 26. Mai 1855 Afsked med Pension. Fra 1811 ? til 1833 var han bosat i Ørkedalen (Orkdal, forf. anm.), naar undtages tvende Gange (sidste Gang i 1827), da han under Vacancer bestyrede Christiansunds Stadslægeembede. Fra 1833 boede han i Surendalen, hvor han døde 12 Juni 1863. Han nød i sin Tid ikke liden Tillid som Læge, navnlig som Accoucheur (mannlig jordmor, fødselslege, forf. anm.), og skal have været i Besiddelse af ualmindelige Legemskræfter.»

Denne beskrivelsen nyanserer det bildet av Bauer som Hans Hyldbakk har gitt i sin Gards- og cettesoge for Surnadal (3). Det bekrefter også at Bauer må ha hatt kontakt med tyske, franske, dansk-norske og svenske miljøer som var vel inne i tidens moter og byggeskikk, og at han har hatt en stilling som har gitt ham økonomisk grunnlag for de moderniseringer han gjorde på huset i Surnadal.

Tapeter til veggdekor ble utviklet fra 1500-tallet og spredte seg blant bedrestilte i hele Europa. Mønstrene var gjerne blomster, blomsterranker, border av stiliserte blomster eller mer geometriske mønstre eller steinimitasjoner. Noen hadde også bilder av livssituasjoner, naturscener eller personer. Noen var håndmalte, men etter hvert ble det vanlig å trykke med utskårne blokker og ulike farger. Mer dempede naturfarger var vanligst til å begynne med, men etter hvert utviklet kjemikere kunstige farger som var mer lyssterke og mer lysbestandige.

Første halvdel av 1800-tallet beskrives som en gullalder for tapeter, spesielt i Frankrike. Det er fra denne tiden vi har djerve fargekombinasjoner som oransje og giftig schweinfurtergrønt (5), kromgult og blått. Å avslutte veggen med en bord øverst var også et element typisk for denne tiden (6). I mer storslåtte saler var tapetdekoren formet som draperier, naturlig utformet og med godt dybdeperspektiv, slik det er illu-

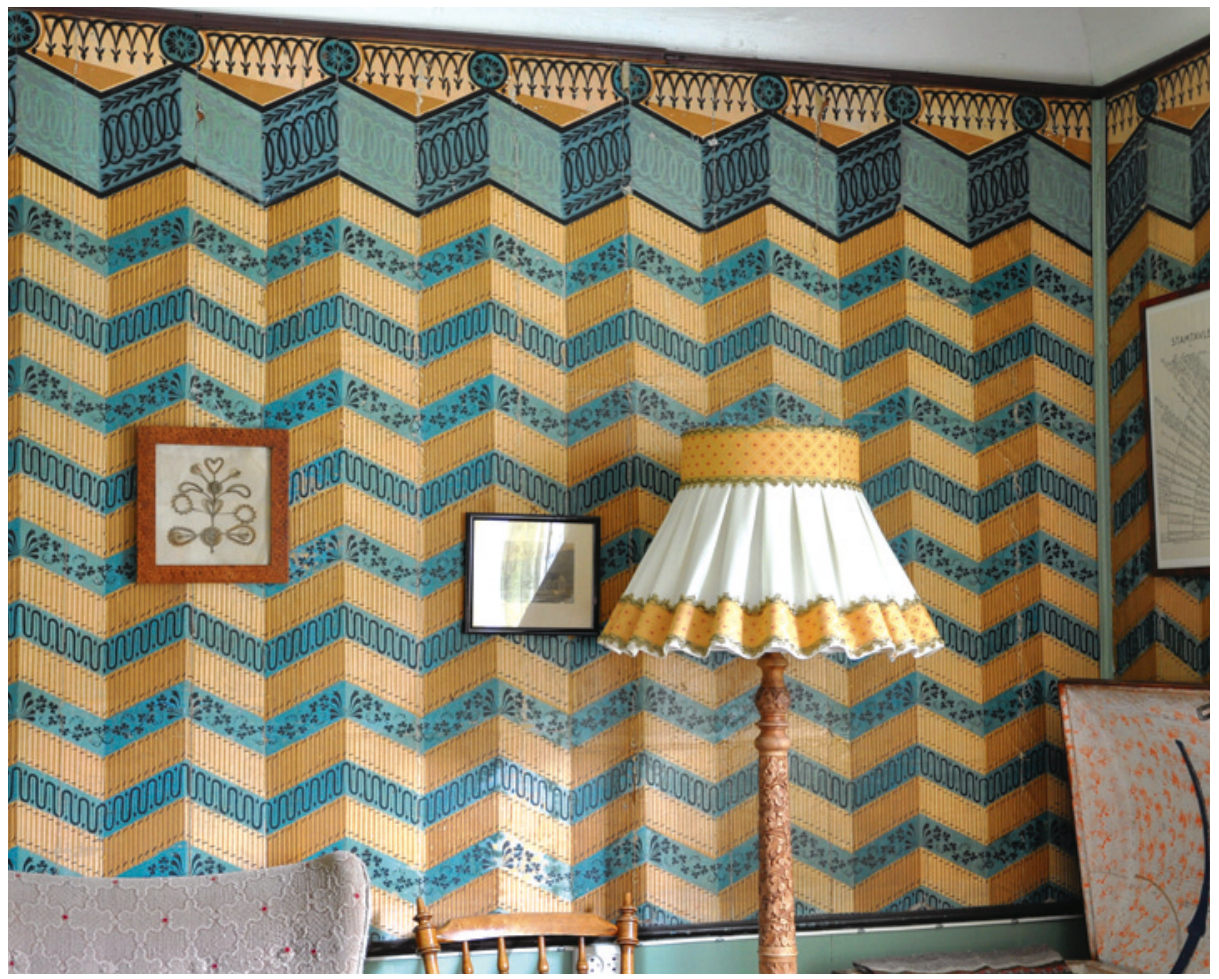

Bildet viser tapetet i Austistua slik det ser ut i dag. Foto: Dag Brekke

strert i en omfattende engelsk fremstilling (7). Frem mot 1850-årene ble fargeprakten noe dempet, og mønstrene forlot empirepreget og tok opp gamle stilelementer fra renessanse, barokk og rokokko i modernisert og tilpasset form.

På en forespørsel til Das Deutsche Tapetenmuseum svarer dr. Astrid Wegener (personlig meddelelse):

«Tapetet er et vakkert eksempel på Empire-tapet fra 1800-1810. Den berømte tyske tapetprodusent Johann Christian Arnold i Kassel laget tilsvarende design, men ikke denne. Designet kan også være fransk. Jeg har forelagt spørsmålet for min franske kollega Bernhard Jacqué. Han anser den for å være fransk fra 1805-10.»

Tapetet fra Austistua er altså en empiretapet med et stilisert draperimotiv, slik moten var i første halvdel av 1800-tallet. Antakelsen om at det var dr. Bauer som innredet sin stue med dette tapetet, kan slik sett støttes med bakgrunn i det vi vet om hans yrkes- og bostedshistorie.

På hvilket tidspunkt og hvor Bauer kjøpte tapetet, kan man bare spekulere på. Men på tapetets sannsynlige produksjonstid var han i tysk-fransk tjeneste og kan ha skaffet seg de nødvendige forbindelser. Bauers historie synes altså å være mer ærerik enn det lokalhistorikeren Hans Hyldbakk ville ha det til.

\section{Dag Brekke (f. 1945)}

er spesialist i allmennmedisin, i samfunnsmedisin og i arbeidsmedisin. Han arbeider som overlege.

Forfatter har fylt ut ICMJE-skjemaet og oppgir ingen interessekonflikter.

\section{Litteratur}

1. Brekke D, Iversen JH, Ødegård O, red. Helsetjenester i Møre og Romsdal gjennom hundre år. Molde: Møre og Romsdal legeforening, 1986.

2. Brekke D. Fra sneppert til MR - Møre og Romsdal legeforening 150 år. Molde: Møre og Romsdal legeforening, 2011

3. Hyldbakk H. Gards- og ættesoge for Surnadal. Surnadal,1947. Rev.utg. 1980: $241 \mathrm{ff}$

4. Larsen $\varnothing$, red. Norges leger. Oslo: Den norske lægeforening, 1996.

5. Broström I, Stavenow-Hidemark E. Tapetboken Papperstapeten i Sverige. Stockholm: Byggförlaget, 2004.

6. Ateva F, Knutson A. Gyllenläder och arseniktapeter - 400 år av tapeter från Kalmar län. Kalmar: Kalmar läns museum, 2008: 18

7. Hoskins L. The papered wall. The history, patterns and techniques of wallpaper. London: Thames \& Hudson, 2005: 69

Mottatt 10.9. 2013 og godkjent 24.9. 2013. Redaktør: Erlend Hem. 